\title{
Het effect van de politierespons in een specifieke zaak op de bereidheid tot medewerking onder slachtoffers van criminaliteit
}

\section{Een vignettenexperiment}

\author{
Nathalie Koster, Michèlle Bal, Joanne van der Leun \& Maarten Kunst
}

\begin{abstract}
In het huidige vignettenexperiment onder 414 studenten in Nederland wordt het effect van de politierespons op de medewerkingsbereidheid verkend en wordt onderzocht of dit verband gemedieerd wordt door percepties van de legitimiteit van de politie. Dit wordt gedaan op basis van Tylers procedurele rechtvaardigheidstheorie en eerder onderzoek onder slachtoffers van criminaliteit. De politierespons werd in het voorgelegde vignette op twee manieren gemanipuleerd: de politie bood een rechtvaardige/onrechtvaardige bejegening en voerde wel/geen opsporingsactiviteiten uit. In een controlegroep werd geen contact met de politie gelegd. De resultaten suggereren een positief effect van de politierespons op medewerkingsbereidheid en impliceren dat deze relatie wordt gemedieerd door gepercipieerd vertrouwen in de politie.
\end{abstract}

Stelt $\mathrm{u}$ zich voor dat $\mathrm{u}$ laat op de avond naar huis loopt. Plotseling wordt $\mathrm{u}$ door iemand benaderd, die van u eist dat $u$ hem uw portemonnee geeft. Wanneer $u$ dit niet direct doet, slaat hij $\mathrm{u}$ in uw gezicht en trapt hij $\mathrm{u}$ in uw maag, waardoor $\mathrm{u}$ op de grond valt. Wanneer $\mathrm{u}$ op de grond ligt, pakt de man uw portemonnee, rent ermee naar zijn scooter en rijdt hard weg. Geschrokken en gewond haast u zich naar huis en belt $u$ de politie. Twee politieagenten arriveren snel en wanneer $u$ de deur voor hen opendoet, vragen zij vriendelijk hoe het met $u$ gaat en of u veel pijn heeft. Vervolgens vragen ze $u$ te vertellen wat er gebeurd is. Daarna stellen ze $u$ een aantal vragen en wanneer ze voldoende informatie hebben, geven ze aan dat ze met u meeleven en dat ze de dader willen pakken. Nadat twee weken zijn verstreken, wordt $\mathrm{u}$ door een van de agenten gebeld. Hij vertelt $\mathrm{u}$ dat ze een buurtonderzoek hebben uitgevoerd en dat ze nog steeds bezig zijn met de zaak.

Zou u bereid zijn opnieuw uw medewerking te verlenen aan de politie, mocht $\mathrm{u}$ opnieuw iets overkomen? Zou uw antwoord anders zijn wanneer de politie lang de tijd nam om te arriveren, niet naar uw verhaal luisterde, bevooroordeeld was en u niet informeerde over de voortgang in uw zaak? Eerder onderzoek suggereert dat uw waarschijnlijkheid om medewerking te verlenen in dat geval zou afnemen. Meer specifiek suggereren studies dat eerdere ervaringen met het doen van aangifte bij de politie zouden kunnen verklaren waarom slachtoffers minder bereid zijn om medewerking te verlenen in geval van herhaald slachtofferschap, maar hebben zelden onderzocht of er sprake is van een oorzakelijk verband (Van Dijk, 2001; Ipsos MORI, 2003; Shapland e.a., 1985; vgl. Wheller e.a., 2013). Aangezien 
de politie vaak afhankelijk is van de medewerking van slachtoffers om misdrijven te kunnen onderzoeken en op te lossen, is het belangrijk om te begrijpen of, en zo ja in welke mate, de politierespons invloed heeft op de medewerkingsbereidheid van slachtoffers. De huidige studie bestaat uit een vignettenexperiment om te exploreren of er een oorzakelijk verband bestaat tussen de politierespons en slachtoffermedewerkingsbereidheid, op basis van Tylers procedurele rechtvaardigheidstheorie (Tyler, 2006; 2011; Tyler \& Huo, 2002; Sunshine \& Tyler, 2003) en eerder onderzoek onder slachtoffers van criminaliteit (De Mesmaecker, 2014; Elliott e.a., 2012).

\section{Theoretisch kader}

Op basis van Tylers procedurele rechtvaardigheidstheorie en eerder onderzoek specifiek onder slachtoffers van criminaliteit wordt verwacht dat de politierespons, in termen van procedurele rechtvaardigheid en opsporingsactiviteiten, van invloed is op de toekomstige medewerkingsbereidheid van slachtoffers aan de politie. Dit zou komen door het effect van de politierespons op de gepercipieerde politielegitimiteit (d.w.z. gepercipieerd vertrouwen in de politie en gepercipieerde verplichting om de wet te gehoorzamen). Meer specifiek wordt verondersteld dat een positieve politierespons beide dimensies van gepercipieerde legitimiteit verhoogt en dat deze verhoogde gepercipieerde legitimiteit tot meer medewerkingsbereidheid zal leiden (zie o.a. Bradford \& Jackson, 2016; Jackson e.a., 2012; Tyler, 2011; Tyler \& Jackson, 2013; Sunshine \& Tyler, 2003).

Tyler identificeerde vier karakteristieke elementen van een procedureel rechtvaardige behandeling: 'voice', neutraliteit, respect en betrouwbaarheid (Tyler, 2006; Tyler \& Lind, 1992). 'Voice' refereert aan politieagenten die iemand de kans geven zijn of haar inzichten op de zaak te uiten. Neutraliteit verwijst naar politieagenten die onbevooroordeeld zijn. Respect heeft betrekking op politieagenten die beleefd en vriendelijk zijn en betrouwbaarheid refereert aan de oprechte intentie van politieagenten om tot de beste oplossing te komen voor alle betrokken partijen. Het politiefunctioneren (d.w.z. opsporingsacties die de politie in een zaak heeft ondernomen) lijkt ook belangrijk te zijn voor slachtoffers (De Mesmaecker, 2014; Elliott e.a., 2012). Hoewel procedurele rechtvaardigheid en het politiefunctioneren theoretisch van elkaar onderscheiden kunnen worden (bejegening vs. opsporingsactiviteiten), zijn beide concepten in de praktijk nauw aan elkaar gerelateerd (De Mesmaecker, 2014; Elliott e.a., 2012) en lijken slachtoffers nauwelijks onderscheid te maken tussen procedurele rechtvaardigheid en het politiefunctioneren in hun evaluatie van het politieoptreden (Koster, 2017). Dit zou verklaard kunnen worden door het simultaan plaatsvinden van bejegening door de politie en (geïnformeerd worden over) opsporingsactiviteiten (zie Van den Bos e.a., 1997), waardoor beide aspecten elkaar beïnvloeden (De Mesmaecker, 2014).

Wanneer het politieoptreden in termen van procedurele rechtvaardigheid en politiefunctioneren positief beschouwd wordt, heeft dat positieve gevolgen voor de gepercipieerde politielegitimiteit volgens het group-value model en group engage- 


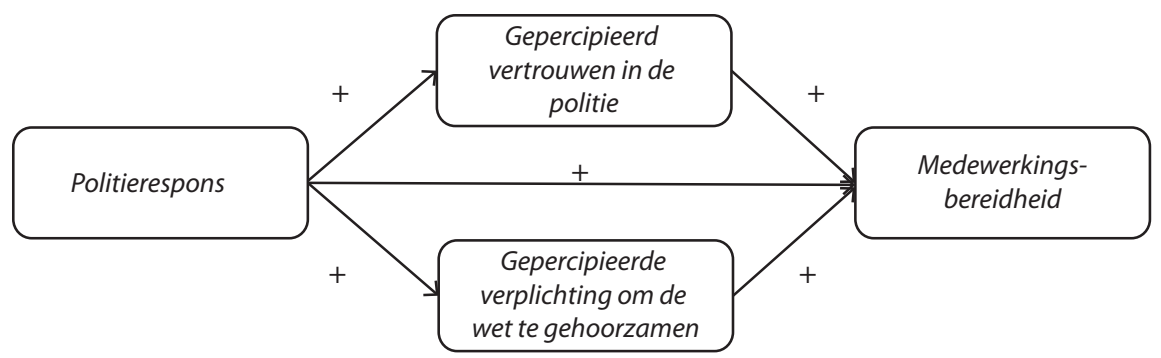

Figuur 1 Grafische weergave van het theoretisch model van de huidige studie

ment model (Tyler \& Blader, 2003). Deze modellen stellen dat mensen het belangrijk vinden om tot een bepaalde groep te behoren en als waardevol lid van die groep gewaardeerd te worden, en dat iemand informatie over diens status binnen de groep kan afleiden uit de wijze waarop diegene behandeld wordt door autoriteiten binnen die groep. Meer specifiek vertaald naar de politie-slachtoffercontext kunnen agenten beschouwd worden als autoriteit binnen de samenleving (Fleming \& McLaughlin, 2012; Tyler; 2011) en kunnen slachtoffers informatie over hun status binnen de samenleving ontlenen aan de wijze waarop de politie reageert op hun zaak. Wanneer agenten slachtoffers op een rechtvaardige wijze bejegenen en opsporingsactiviteiten uitvoeren, krijgen slachtoffers het gevoel dat zij en hun zaak serieus genomen worden (De Mesmaecker, 2014) en dat de politie als organisatie zich inzet om de normen en waarden in de samenleving te handhaven (d.w.z. politielegitimiteit). Dit uit zich niet alleen in meer vertrouwen in de politieorganisatie, maar ook in een intern gevoelde verplichting om zelf gehoorzaam te zijn aan de wet. Gepercipieerde politielegitimiteit roept op haar beurt een intrinsiek verantwoordelijkheidsgevoel op om bij te dragen aan de orde in de samenleving en zou medewerkingsbereidheid vergroten (zie figuur 1; zie ook De Mesmaecker, 2014; Elliott e.a., 2012; Sunshine \& Tyler, 2003; Tyler, 2006; 2011; Tyler \& Jackson, 2013).

Anderzijds leiden een onrechtvaardige bejegening en het niet uitvoeren van opsporingsactiviteiten tot het gevoel dat slachtoffers en hun zaak niet serieus genomen worden, en dus dat de politie als organisatie zich niet inzet om de normen en waarden in de samenleving te handhaven. Als gevolg hiervan zou de gepercipieerde politielegitimiteit afnemen en daarmee ook de medewerkingsbereidheid.

\section{Eerder onderzoek onder slachtoffers van criminaliteit}

Een systematische literatuurreview (Koster e.a., 2016) suggereert dat het theoretisch kader van de huidige studie ten dele wordt ondersteund door eerder onderzoek onder slachtoffers van criminaliteit. De meeste studies betrokken in de review baseerden zich echter op correlationele data, die ongeschikt zijn om oorza- 
kelijke verbanden te toetsen. Een uitzondering hierop is de experimentele studie van Wheller e.a. (2013), die uitgevoerd werd in Manchester (Verenigd Koninkrijk).

In hun veldexperiment werd een groep agenten expliciet getraind om slachtoffers op een procedureel rechtvaardige wijze te bejegenen, terwijl een andere groep agenten niet expliciet daarin getraind werd. Slachtoffers die contact hadden gehad met agenten van een van beide groepen werd vervolgens gevraagd om hun medewerkingsbereidheid aan te geven. In deze studie werd geen statistisch significant verschil in medewerkingsbereidheid gevonden tussen slachtoffers die contact hadden gehad met expliciet in procedurele rechtvaardigheid getrainde agenten en slachtoffers die contact hadden gehad met niet daartoe expliciet getrainde agenten. De auteurs suggereren dat de training mogelijk geen effect had omdat de meeste slachtoffers al zeer medewerkingsbereid waren. Een alternatieve verklaring zou kunnen zijn dat de studie zich exclusief richtte op procedurele rechtvaardigheid en daarmee voorbijging aan politiefunctioneren, terwijl dit laatste ook belangrijk lijkt te zijn voor slachtoffers van criminaliteit (zie Aviv \& Weisburd, 2016; De Mesmaecker, 2014; Elliott e.a., 2012). Bovendien zou de wetenschap dat de studie uitgevoerd werd, agenten in beide groepen meer alert hebben gemaakt om slachtoffers in ieder geval niet op een procedureel onrechtvaardige wijze te bejegenen, terwijl dit wel voor zou kunnen komen in de dagelijkse praktijk.

Om vanzelfsprekende redenen zou het onethisch en onhaalbaar zijn om procedurele rechtvaardigheid en politiefunctioneren op negatieve wijze te manipuleren in een veldexperiment. Daarentegen kan de politierespons wel gemanipuleerd worden in een vignettenexperiment, wat een van de belangrijkste voordelen van de huidige studie is. In een vignettenexperiment wordt deelnemers gevraagd zichzelf in een bepaalde hypothetische situatie te plaatsen. Om deelnemers dat te kunnen laten doen, is het noodzakelijk dat de beschreven situatie realistisch en geloofwaardig overkomt (Leeper Piquero \& Piquero, 2006).

\section{De huidige studie}

De huidige vignettenstudie beantwoordt de volgende onderzoeksvraag:

In hoeverre heeft de politierespons invloed op de medewerkingsbereidheid van mock slachtoffers ${ }^{1}$ van criminaliteit in geval van toekomstig slachtofferschap en wordt een eventueel direct effect gemedieerd door gepercipieerde legitimiteit van de politie?

Hierbij zijn de volgende hypotheses en subhypotheses geformuleerd:

H1: De politierespons heeft een direct positief effect op medewerkingsbereidheid.

1 De term mock slachtoffers wordt gebruikt om te refereren naar de respondenten in de huidige studie die zich voorstellen slachtoffer geworden te zijn van een delict. 
H1a: Een positieve politierespons leidt tot hogere medewerkingsbereidheid in vergelijking met de controlegroep.

H1b: Een negatieve politierespons leidt tot lagere medewerkingsbereidheid in vergelijking met de controlegroep.

H2: De politierespons heeft een indirect positief effect op medewerkingsbereidheid via het positieve effect op de mediërende concepten gepercipieerd vertrouwen in de politie en gepercipieerde verplichting om de wet te gehoorzamen (d.w.z. gepercipieerde legitimiteit).

H2a: Een positieve politierespons leidt tot hogere gepercipieerde legitimiteit in vergelijking met de controlegroep.

H2b: Een negatieve politierespons leidt tot lagere gepercipieerde legitimiteit in vergelijking met de controlegroep.

H2c: De politierespons heeft een positief effect op medewerkingsbereidheid via gepercipieerd vertrouwen in de politie.

H2d: De politierespons heeft een positief effect op medewerkingsbereidheid via gepercipieerde verplichting om de wet te gehoorzamen.

Op basis van eerder onderzoek onder slachtoffers van criminaliteit dat suggereert dat slachtoffers geen onderscheid maken tussen evaluaties van procedurele rechtvaardigheid en politiefunctioneren (De Mesmaecker, 2014; Koster, 2017), worden deze aspecten van de politie samengenomen in de politierespons.

Op basis van eerder onderzoek onder burgers in het algemeen (zie Jackson \& Gau, 2016; Reisig e.a., 2007) en onder slachtoffers specifiek (Koster, 2017) dat suggereert dat gepercipieerd vertrouwen in de politie en gepercipieerde verplichting om de wet te gehoorzamen niet alleen empirisch, maar ook theoretisch van elkaar onderscheiden moeten worden, worden deze aspecten van legitimiteit separaat geïncludeerd in het te toetsen model. Gepercipieerd vertrouwen ziet namelijk op de perceptie dat de politie zich inzet om de normen en waarden in de samenleving te bekrachtigen en motiveert coöperatie via positieve verwachtingen over hoe de politie in het algemeen haar taak uitvoert, terwijl gepercipieerde verplichting om de wet te gehoorzamen refereert aan de perceptie dat de politie gemachtigd is om gepast gedrag voor te schrijven (zie Jackson \& Gau, 2016). Om een complex concept als vertrouwen in de politie op meer betrouwbare wijze te kunnen meten, zijn meerdere vragen gesteld over het gepercipieerde vertrouwen in de politie in plaats van één enkele vraag (Van Damme e.a., 2012). Daarnaast ligt de focus op de gepercipieerde verplichting om de wet te gehoorzamen en niet op de gepercipieerde verplichting om de politie te gehoorzamen, omdat de eerste een meer accurate weergave biedt van een intrinsiek gevoelde verplichting om zich te gedragen volgens de geldende normen en waarden in een samenleving, zelfs wanneer er geen externe prikkels zijn om dat te doen (zie Tyler, 2006).

Waar eerdere vignettenstudies zich beperkten tot de bereidheid tot het doen van aangifte als indicator voor medewerkingsbereidheid (bijv. Boekhoorn \& Tolsma, 2015; Goudriaan \& Nieuwbeerta, 2007; Tolsma, e.a., 2012), wordt medewerkingsbereidheid in de huidige studie breder onderzocht. Hierbij wordt niet alleen 
gevraagd naar de bereidheid tot het doen van aangifte, maar bijvoorbeeld ook naar de bereidheid tot het helpen van de politie bij het vinden van een verdachte en de bereidheid om de politie toe te staan om de plaats delict te onderzoeken. Op deze wijze kan een vollediger en betrouwbaarder beeld geschetst worden van de medewerkingsbereidheid.

De huidige studie draagt bij aan kennis over de invloed van de politierespons op de medewerkingsbereidheid aan de politie in geval van toekomstig slachtofferschap op drie belangrijke wijzen. Ten eerste exploreert deze studie of er sprake is van een direct oorzakelijk verband tussen de politierespons en de bereidheid van mock slachtoffers om medewerking te verlenen aan de politie in geval van herhaald slachtofferschap. Ten tweede onderzoekt deze studie niet alleen of een negatief politieoptreden een schadelijk effect heeft op de gepercipieerde legitimiteit van de politie en de medewerkingsbereidheid, maar ook of een positief politieoptreden een bevorderlijk effect heeft op de gepercipieerde legitimiteit en de medewerkingsbereidheid, in vergelijking met mock slachtoffers die geen contact met de politie hebben gehad. Ten derde exploreert deze studie of het verband tussen de politierespons en de medewerkingsbereidheid kan worden verklaard (gemedieerd) door gepercipieerde legitimiteit van de politieorganisatie.

\section{Methoden}

\section{Participanten}

In totaal participeerden 414 studenten van de Universiteit Leiden (165 mannen, 247 vrouwen; twee deelnemers hadden hun geslacht niet aangegeven) in de studie. ${ }^{2}$ Hun leeftijd varieerde van 18 tot 46 (M=20,59, SD=2,89). 24 van deze participanten hadden aangegeven dat zij in de afgelopen twaalf maanden slachtoffer van criminaliteit waren geworden. Van deze personen hadden vijftien de politie daarover geïnformeerd en negen van hen waardeerden dat contact met de politie als positief. Het includeren van deze participanten had geen effect op de resultaten. Zij zijn daarom meegenomen in de analyses.

\section{Design}

De studie contrasteerde drie condities: een positieve politierespons $(n=138)$, een negatieve politierespons ( $n=138)$ en een controleconditie $(n=138)$, waarin de poli-

2 Het minimumaantal respondenten per groep werd vastgesteld op 46. Dit werd berekend via een a priori power-analyse d.m.v. GPOWER (Erdfelder e.a., 1996; Faul \& Erdfelder, 1992) op basis van een pilotstudie onder 75 studenten (17 mannen en 58 vrouwen) van de Universiteit Leiden. Dit aantal werd gebaseerd op een vuistregel die suggereert dat minimaal 70 deelnemers noodzakelijk zijn voor een dergelijke pilotstudie (Teare e.a., 2014). De leeftijd van de participanten varieerde van 18 tot $49(\mathrm{M}=19,32, \mathrm{SD}=3,75)$. De pilotstudie bestond uit twee experimentele condities, waarin het politieoptreden op dezelfde manier was gemanipuleerd als in de huidige studie (positieve politierespons en negatieve politierespons). Vervolgens maten we de effectgrootte van de relatie tussen het politieoptreden en medewerkingsbereidheid. Gebaseerd op een effectgrootte $(\mathrm{d})$ van 0.526 , een alpha $(\alpha)$ van 0.05 , een gewenste power van 0.80 en een verdelingsratio van N2/N1 van 1 (d.w.z. gelijke deelnemersaantallen in beide groepen) werd het minimumaantal deelnemers bepaald op 46 . 
tierespons niet werd gemanipuleerd (in deze conditie had het slachtoffer geen contact met de politie). De controleconditie informeert ons over de algemene bereidheid van mock slachtoffers om medewerking te verlenen aan de politie, wat zou kunnen helpen om de resultaten van de experimentele condities te interpreteren. Respondenten werden willekeurig verdeeld over de drie condities.

\section{Procedure}

Bachelorstudenten van de faculteiten Sociale Wetenschappen en Geesteswetenschappen van de Universiteit Leiden werden benaderd tijdens de lunchpauze. $\mathrm{Na}$ een korte introductie van het onderzoek werd hun na instemming een vragenlijst voorgelegd en werd de vrijwilligheid van deelname aan de studie benadrukt. Vervolgens lazen participanten een hypothetische situatie van een gewelddadige overval en werd hun gevraagd om zichzelf voor te stellen als het slachtoffer in het scenario (zie de appendix). In de controleconditie eindigde het verhaal na het slachtofferschap. In de experimentele condities had het slachtoffer na het slachtofferschap contact met de politie. Na het lezen van het scenario werd alle deelnemers gevraagd om vragen over de legitimiteit van de politieorganisatie en hun medewerkingsbereidheid in geval van toekomstig slachtofferschap te beantwoorden. Tot slot werd een aantal controlevragen en demografische vragen gesteld. Tijdens het lezen van het scenario en het invullen van de vragenlijst wisten deelnemers niet dat het onderzoek uit verschillende condities bestond en de eerste auteur zorgde ervoor dat deelnemers niet met elkaar communiceerden gedurende het onderzoek. Het lezen van het scenario en invullen van de vragenlijst duurde ongeveer tien minuten, waarna de deelnemers werden bedankt en geïnformeerd over het doel van het onderzoek.

\section{Manipulatie van de politierespons ${ }^{3}$}

De politierespons werd op twee wijzen gemanipuleerd: de politie bood een rechtvaardige/onrechtvaardige bejegening en voerde wel/geen opsporingsactiviteiten uit (zie de eerste alinea voor een indruk van het scenario en de appendix voor het volledige scenario). Om er zeker van te zijn dat deelnemers in de experimentele condities het scenario goed hadden gelezen, vroegen wij hun om te herinneren of de agenten snel kwamen, of het slachtoffer zijn/haar verhaal kon vertellen en of de politie na het eerste contact nog contact met het slachtoffer had opgenomen. De meeste respondenten beantwoordden deze drie vragen correct. Slechts twee participanten slaagden er niet in om twee van deze vragen juist te beantwoorden

3 De effectiviteit van deze manipulatie in het oproepen van positieve dan wel negatieve evaluaties van het politieoptreden werd eveneens getoetst in de in noot 2 beschreven pilotstudie onder 75 studenten (17 mannen en 58 vrouwen) van de Universiteit Leiden. Voor de twee condities (positieve en negatieve politierespons) maten we de effectiviteit van het scenario in het opwekken van positieve waardering dan wel minder positieve waardering van het politieoptreden. Een t-test gaf aan dat participanten in de positieve politieresponsconditie significant hogere scores rapporteerden dan in de negatieve politieresponsconditie $(M=5,02$, $\mathrm{SD}=0,70$ vs. $\mathrm{M}=2,00, \mathrm{SD}=0.52, \mathrm{t}(46)=-17.034, \mathrm{p}<.001, \mathrm{~d}=4,90)$. Dit resultaat impliceert dat de manipulatie van het politieoptreden succesvol was in het oproepen van positieve dan wel negatieve evaluaties van het politieoptreden. 
en geen van de participanten had alle drie de vragen onjuist beantwoord. Het includeren van deze participanten had geen effect op de resultaten. Zij zijn daarom meegenomen in de analyses.

\section{Meetinstrumenten}

\section{Mediators}

\section{- Gepercipieerde legitimiteit}

In lijn met Tylers originele werk $(2006,47)$ gebruikten we twee indicatoren om gepercipieerde legitimiteit te meten: gepercipieerde verplichting om de wet te gehoorzamen en gepercipieerd vertrouwen in de politie. Op basis van eerder empirisch onderzoek worden deze concepten als gescheiden indicatoren van gepercipieerde legitimiteit behandeld (zie Jackson \& Gau, 2016; Koster, 2017; Reisig e.a., 2007).

\section{- Gepercipieerde verplichting om de wet te gehoorzamen}

Deelnemers werd gevraagd om aan te geven in hoeverre zij het eens waren met drie stellingen (bijv. 'Ik probeer altijd de wet te volgen, zelfs als ik denk dat het fout is') op een 7-punts Likertschaal, variërend van (1) geheel oneens tot (7) geheel eens (zie Wemmers, 1996). De interne betrouwbaarheid van deze schaal was voldoende in de huidige studie $(\alpha=.72)$.

\section{- Gepercipieerd vertrouwen in de politie}

Deelnemers werd gevraagd om aan te geven in hoeverre zij het eens waren met vier stellingen (bijv. 'Ik heb veel respect voor de politie') op een 7-punts Likertschaal, variërend van (1) geheel oneens tot (7) geheel eens (zie Wemmers, 1996). De interne betrouwbaarheid van deze schaal was uitstekend in de huidige studie $(\alpha=.86)$.

\section{Afhankelijke variabele}

\section{- Medewerkingsbereidheid}

Deelnemers werd gevraagd om aan te geven in hoeverre zij bereid waren tot het verlenen van medewerking aan de politie in geval van toekomstig slachtofferschap aan de hand van vijf vragen (bijv. 'Als ik in de toekomst slachtoffer zou worden van een geweldsmisdrijf, zou ik de politie helpen om een verdachte te vinden') op een 7-punts Likertschaal, variërend van (1) zeer onwaarschijnlijk tot (7) zeer waarschijnlijk (zie Reisig e.a., 2007; Sunshine \& Tyler, 2003). De interne betrouwbaarheid van deze schaal was uitstekend in de huidige studie $(\alpha=.88)$.

\section{- Manipulatie controle}

Om het gepercipieerde realisme van de scenario's te toetsen, vroegen we deelnemers om aan te geven of zij zich eenvoudig in de beschreven situatie konden plaatsen (ja/nee) en of ze zich konden voorstellen dat zoiets als de beschreven 
situatie zou kunnen gebeuren in het echte leven (ja/nee). Twee chikwadraattoetsen wezen uit dat het gepercipieerde realisme van de scenario's (of het eenvoudig was om zichzelf in de beschreven situatie te plaatsen, $\chi^{2}(2, \mathrm{~N}=414)=0.266, \mathrm{p}>.05$, en of het scenario in het echte leven zou kunnen gebeuren, $\chi^{2}(2, N=414)=5.038$, p >.05) niet afhankelijk was van de condities. Dit impliceert dat het gepercipieerde realisme van de scenario's niet varieerde over de condities.

\section{Statistische analyses}

Om te onderzoeken in hoeverre de politierespons van invloed is op de gepercipieerde legitimiteit van de politie en de medewerkingsbereidheid in geval van herhaald slachtofferschap, werden drie een-weg ANOVA's uitgevoerd. Hiermee konden we toetsen (1) of er een causaal verband bestaat tussen de politierespons en medewerkingsbereidheid; (2) of een positief politieoptreden de gepercipieerde legitimiteit van de politie en medewerkingsbereidheid verhoogt; en (3) of een negatief politieoptreden de gepercipieerde legitimiteit van de politie en medewerkingsbereidheid verlaagt. Wanneer een significant verschil gevonden werd tussen de drie condities, werd Tukey's HSD post-hoc test gebruikt om te onderzoeken welke condities significant van elkaar verschilden. Aangezien drie ANOVA's werden uitgevoerd, testten we of de resultaten significant zouden blijven wanneer de Bonferroni-correctie van $\mathrm{p}<.0167$ ( $\mathrm{p}<.05 / 3$ ) werd toegepast.

$\mathrm{Om}$ na te gaan of gepercipieerde legitimiteit het verband tussen de politierespons en de medewerkingsbereidheid aan de politie medieert, voerden we een meervoudige mediatieanalyse uit. Dit is een mediatiemodel dat twee mediatievariabelen bevat (gepercipieerd vertrouwen in de politie en gepercipieerde verplichting om de wet te gehoorzamen). Om het meervoudige mediatiemodel te testen wordt gebruik gemaakt van een SPSS-macro, die de significantie van de indirecte effecten test met behulp van bootstrap-analyse (Preacher \& Hayes, 2008). Deze analyse gebruikt de originele steekproefdata om meerdere willekeurige steekproeven met teruglegging te trekken en kan op die manier herhaaldelijk een statische waarde berekenen (Mallinckrodt e.a., 2006). In de huidige studie werden 10.000 steekproeven opgevraagd om de parameterschattingen en de bijbehorende betrouwbaarheidsintervallen van de totale en specifieke indirecte effecten te berekenen. Een specifiek indirect effect wordt berekend als het product van het effect van de politierespons op de medewerkingsbereidheid via ofwel gepercipieerd vertrouwen in de politie $\left(a_{1} b_{1}\right)$, ofwel gepercipieerde verplichting tot het gehoorzamen van de wet $\left(a_{2} b_{2}\right)$, terwijl het totale effect (c) wordt berekend als de som van het indirecte effect van beide mediators in het model en het directe effect $\left(\left[a_{1} b_{1}\right]+\left[a_{2} b_{2}\right]+c\right.$ '; zie figuur 2$)$.

Als de betrouwbaarheidsintervallen van de specifieke indirecte effecten niet de nulwaarde bevatten, betekent het dat de effecten significant zijn en dat er sprake is van mediatie. Indien hiervan sprake was, werd de significantie van het indirecte effect ook getoetst met de Sobel-test (1982). Deze test gaat na of het indirecte effect op een afhankelijke variabele via een bepaalde mediator significant verschilt van nul. Als er sprake was van mediatie, werd de effectgrootte berekend in 


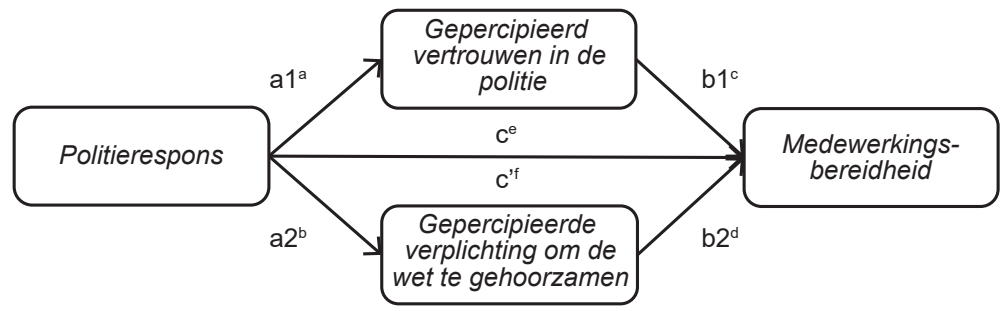

\begin{abstract}
a Direct effect van de politierespons op gepercipieerd vertrouwen in de politie.
${ }^{b}$ Direct effect van de politierespons op gepercipieerde verplichting om de wet te gehoorzamen.

${ }^{c}$ Direct verband tussen gepercipieerd vertrouwen in de politie en medewerkingsbereidheid.

d Direct verband tussen gepercipieerde verplichting om de wet te gehoorzamen en medewerkingsbereidheid.

e Totaal effect (som van de specifieke indirecte effecten van de politierespons op medewerkingsbereidheid via gepercipieerd vertrouwen in de politie en gepercipieerde verplichting om de wet te gehoorzamen en het direct effect van de politierespons op medewerkingsbereidheid). ${ }^{f}$ Direct effect van de politierespons op medewerkingsbereidheid (oftewel totaal effect minus de specifieke indirecte effecten).
\end{abstract}

\title{
Figuur 2 Grafische weergave van het meervoudige mediatiemodel in de huidige studie
}

termen van het indirecte effect relatief aan het totale effect en het indirecte effect relatief aan het directe effect (Preacher \& Kelley, 2011). Alle analyses werden uitgevoerd met behulp van IBM SPSS Statistics 23.

\section{Resultaten}

Drie een-weg ANOVA's werden uitgevoerd om het effect van de politierespons op de medewerkingsbereidheid met de politie onder mock slachtoffers, het gepercipieerde vertrouwen in de politie en de gepercipieerde verplichting om de wet te gehoorzamen te vergelijken tussen de positieve politieresponsconditie, de negatieve politieresponsconditie en de controleconditie (geen politiecontact). Hiermee werden de hypotheses H1 (de politierespons heeft een direct positief effect op medewerkingsbereidheid), $\mathrm{H} 1 \mathrm{a}$ (een positieve politierespons leidt tot hogere medewerkingsbereidheid in vergelijking met de controlegroep), H1b (een negatieve politierespons leidt tot lagere medewerkingsbereidheid in vergelijking met de controlegroep), H2a (een positieve politierespons leidt tot hogere gepercipieerde legitimiteit in vergelijking met de controlegroep) en H2b (een negatieve politierespons leidt tot lagere gepercipieerde legitimiteit in vergelijking met de controlegroep) getoetst. Significante verschillen werden gevonden tussen deze drie condities voor medewerkingsbereidheid $(\mathrm{F}[2,411]=62.43, \mathrm{p}<.001)$, gepercipieerd vertrouwen in de politie $(\mathrm{F}[2,411]=54.61, \mathrm{p}<.001)$ en gepercipieerde verplichting om de wet te gehoorzamen $(\mathrm{F}[2,411]=20.74$, $\mathrm{p}<.001)$.

Tabel 1a geeft de gemiddelde scores en standaarddeviaties weer voor alle uitkomstmaten per conditie. De resultaten van de post-hocanalyses zijn weergegeven in tabel $1 \mathrm{~b}$ en indiceren dat de gemiddelde scores op alle uitkomstmaten medewerking, gepercipieerd vertrouwen en gepercipieerde verplichting om de wet 
Tabel 1a Gemiddelde scores op uitkomstmaten per conditie $(N=414)$

\begin{tabular}{lllllll}
\hline & \multicolumn{2}{l}{$\begin{array}{l}\text { Positieve } \\
\text { conditie }\end{array}$} & \multicolumn{2}{c}{$\begin{array}{l}\text { Negatieve } \\
\text { conditie }\end{array}$} & \multicolumn{2}{c}{$\begin{array}{c}\text { Controle- } \\
\text { conditie }\end{array}$} \\
Afhankelijke variabele & M & SD & M & SD & M & SD \\
\hline Medewerkingsbereidheid & 6.25 & 0.64 & 5.13 & 1.10 & 5.97 & 0.80 \\
$\begin{array}{l}\text { Gepercipieerd vertrouwen in de poli- } \\
\text { tie }\end{array}$ & 5.10 & 0.93 & 3.87 & 1.13 & 4.79 & 0.98 \\
$\begin{array}{l}\text { Gepercipieerde verplichting om de } \\
\text { wet te gehoorzamen }\end{array}$ & 5.09 & 0.90 & 4.43 & 0.87 & 4.77 & 0.79 \\
\hline
\end{tabular}

Tabel 1b Gemiddelde verschillen tussen condities op uitkomstmaten $(N=414)$

\begin{tabular}{|c|c|c|c|c|}
\hline $\begin{array}{l}\text { Afhankelijke varia- } \\
\text { bele }\end{array}$ & $\begin{array}{l}\text { Conditie } \\
\text { (I) }\end{array}$ & $\begin{array}{l}\text { Conditie } \\
\text { (2) }\end{array}$ & $\begin{array}{l}\text { Gemiddeld } \\
\text { verschil }(I-2)\end{array}$ & Cohen's d \\
\hline \multirow{3}{*}{$\begin{array}{l}\text { Medewerkingsbereid- } \\
\text { heid }\end{array}$} & Positief & Negatief & 1.12 & $1.25 * * *$ \\
\hline & & Controle & 0.28 & $0.39 *$ \\
\hline & Controle & Negatief & 0.84 & $0.87 * * *$ \\
\hline \multirow{3}{*}{$\begin{array}{l}\text { Gepercipieerd ver- } \\
\text { trouwen in de politie }\end{array}$} & Positief & Negatief & 1.23 & $1.19 * * *$ \\
\hline & & Controle & 0.31 & $0.32 *$ \\
\hline & Controle & Negatief & 0.92 & $0.87 * * *$ \\
\hline \multirow{3}{*}{$\begin{array}{l}\text { Gepercipieerde ver- } \\
\text { plichting om de wet te } \\
\text { gehoorzamen }\end{array}$} & Positief & Negatief & 0.66 & $0.75 * * *$ \\
\hline & & Controle & 0.32 & $0.38 * *$ \\
\hline & Controle & Negatief & 0.34 & $0.41 * *$ \\
\hline
\end{tabular}

$* \mathrm{p}<.05 ; * * \mathrm{p}<.01 ; * * * \mathrm{p}<.001$

te gehoorzamen - voor de positieve politieresponsconditie significant hoger waren dan voor de controleconditie en ondersteunen daarmee de hypotheses $\mathrm{H} 1 \mathrm{a}$ en H2a. Deze resultaten suggereren dat een positieve politierespons de gepercipieerde legitimiteit van de politie en de medewerkingsbereidheid verhogen in vergelijking met het geen contact hebben met de politie. Daarnaast waren de gemiddelde scores voor de controleconditie significant hoger dan voor de negatieve politieresponsconditie. Dit suggereert dat een negatieve politierespons de gepercipieerde legitimiteit en de medewerkingsbereidheid verlaagt in vergelijking met het geen contact hebben met de politie en ondersteunt de hypotheses H1b en $\mathrm{H} 2 \mathrm{~b}$. Alle significante resultaten bleven bestaan na toepassing van de Bonferronicorrectie, behalve de verschillen tussen de positieve conditie en de controleconditie op gepercipieerd vertrouwen en medewerkingsbereidheid. Dit betekent dat de hypotheses H1a en H2a slechts ten dele werden ondersteund. 
Om na te gaan of het directe verband tussen de politierespons en de medewerkingsbereidheid wordt gemedieerd door de gepercipieerde legitimiteit van de politie, werd een meervoudige mediatieanalyse uitgevoerd, waarmee de hypotheses H2c (de politierespons heeft een positief effect op medewerkingsbereidheid via gepercipieerd vertrouwen in de politie) en H2d (de politierespons heeft een positief effect op medewerkingsbereidheid via gepercipieerde verplichting om de wet te gehoorzamen) werden getoetst. Tabel 2 geeft de parameterschattingen voor de relaties tussen de politierespons en gepercipieerde legitimiteit en tussen gepercipieerde legitimiteit en medewerkingsbereidheid weer. Daarnaast zijn in deze tabel de parameterschattingen voor het totale effect, het directe effect en de specifieke indirecte effecten weergegeven voor de relatie tussen de politierespons en de medewerkingsbereidheid onder mock slachtoffers via gepercipieerd vertrouwen in de politie en gepercipieerde verplichting om de wet te gehoorzamen. Het indirecte effect via de gepercipieerde verplichting om de wet te gehoorzamen was niet significant (verwerping van hypothese H2d), in tegenstelling tot het indirecte effect via gepercipieerd vertrouwen in de politie (ondersteuning van hypothese H2c). Dit geeft aan dat gepercipieerd vertrouwen in de politie een significante mediator is op de wijze dat de politierespons een positief en direct effect heeft op gepercipieerd vertrouwen in de politie en dat het gepercipieerd vertrouwen positief en direct verband houdt met de medewerkingsbereidheid aan de politie (zie figuur 3). Het mediatie-effect werd bevestigd door een Sobel-test $(z=7.75, p<$. 001).

Om de sterkte van het indirecte effect te interpreteren, rapporteren wij twee effectgroottematen: de ratio van het indirecte effect op het totale effect $\left(\mathrm{P}_{\mathrm{M}}\right.$; Alwin \& Hauser, 1975) en de ratio van het indirecte effect op het directe effect $\left(\mathrm{R}_{\mathrm{M}}\right.$; Sobel, 1982). De $\mathrm{P}_{\mathrm{M}^{-}}$-effectgrootte was 0,59 (CI=.440-.769), suggererend dat gepercipieerd vertrouwen iets meer dan de helft van het totale effect van de politierespons op medewerking medieert (Alwin \& Hauser, 1975). De $\mathrm{R}_{\mathrm{M}^{-}}$effectgrootte was 1,35 ( $\mathrm{CI}=.751-3.047)$, indicerend dat het directe effect van de politierespons op medewerking 1,35 keer de grootte van het directe effect is (Sobel, 1982). Tezamen suggereren de effectgrootten dat het mediatie-effect van gepercipieerd vertrouwen in de politie op de relatie tussen de politierespons en de medewerkingsbereidheid onder mock slachtoffers sterk was.

\section{Discussie}

Op basis van Tylers theoretisch kader rond procedurele rechtvaardigheid en eerder onderzoek onder slachtoffers van criminaliteit (De Mesmaecker, 2014; Elliott e.a., 2012) exploreerde de huidige studie of de politierespons causaal verband houdt met de medewerkingsbereidheid aan de politie in geval van toekomstig slachtofferschap en of deze relatie gemedieerd wordt door de gepercipieerde legitimiteit van de politie door het uitvoeren van een vignettenexperiment. Door gebruik te maken van een vignettenexperiment werd de politierespons op twee 
Tabel 2 Totale en indirecte effecten van de politierespons op de medewerkingsbereidheid via de gepercipieerde legitimiteit van de politie en individuele parameters $(n=276)$

\begin{tabular}{|c|c|c|c|c|}
\hline & \multirow{2}{*}{$\begin{array}{l}\text { Parameter- } \\
\text { schatting }\end{array}$} & \multirow[t]{2}{*}{ SE } & \multicolumn{2}{|c|}{$95 \% \mathrm{BC} \mathrm{Cl}$} \\
\hline & & & Laagste & Hoogste \\
\hline $\begin{array}{l}\text { Politierespons - } \\
\text { gepercipieerd } \\
\text { vertrouwen (al) }\end{array}$ & 1.08 & .11 & .862 & 1.291 \\
\hline $\begin{array}{l}\text { Politierespons - } \\
\text { gepercipieerde } \\
\text { verplichting om } \\
\text { de wet te gehoor- } \\
\text { zamen (bl) }\end{array}$ & 0.74 & .12 & .506 & .975 \\
\hline $\begin{array}{l}\text { Gepercipieerd } \\
\text { vertrouwen - } \\
\text { medewerkingsbe- } \\
\text { reidheid (a2) }\end{array}$ & 0.58 & .05 & .476 & .684 \\
\hline $\begin{array}{l}\text { Gepercipieerde } \\
\text { verplichting om } \\
\text { de wet te gehoor- } \\
\text { zamen - mede- } \\
\text { werkingsbereid- } \\
\text { heid (b2) }\end{array}$ & 0.04 & .05 & -.052 & .139 \\
\hline Totaal effect ${ }^{\mathrm{a}}$ & 1.12 & .11 & .907 & 1.333 \\
\hline Direct effect ${ }^{b}$ & 0.46 & .10 & .264 & .652 \\
\hline $\begin{array}{l}\text { Indirect effect via } \\
\text { gepercipieerd } \\
\text { vertrouwen in de } \\
\text { politiec }^{c}\end{array}$ & 0.63 & .10 & .452 & .827 \\
\hline $\begin{array}{l}\text { Indirect effect via } \\
\text { gepercipieerde } \\
\text { verplichting om } \\
\text { de wet te gehoor- } \\
\text { zamen }^{\text {d }}\end{array}$ & 0.03 & .05 & -.056 & .122 \\
\hline
\end{tabular}

$\mathrm{BC} \mathrm{Cl}=$ voor bias gecorrigeerde betrouwbaarheidsinterval

a Som van specifieke indirecte effecten en directe effect (c-pad).

b Totale effect minus specifieke indirecte effecten (c'-pad).

c Specifieke indirecte effect van de politierespons op de medewerkingsbereidheid via gepercipieerd vertrouwen in de politie (a l bl).

d Specifieke indirecte effect van de politierespons op de medewerkingsbereidheid via gepercipieerde verplichting om de wet te gehoorzamen $(\mathrm{a} 2 \mathrm{~b} 2)$.

$* \mathrm{p}<.05 ; * * \mathrm{p}<.01 ; * * * \mathrm{p}<.001$

wijzen gemanipuleerd (een positieve en een negatieve politierespons) om het effect daarvan te onderzoeken op de gepercipieerde politielegitimiteit en medewerkingsbereidheid onder mock slachtoffers van criminaliteit. Daarnaast werd een controleconditie toegevoegd, waarin de politierespons niet werd gemanipuleerd, om de studieresultaten te kunnen interpreteren.

Overeenkomstig hypothese $\mathrm{H} 1$ en de meeste voorgaande studies onder echte slachtoffers suggereerden de resultaten van de huidige studie dat de politiere- 


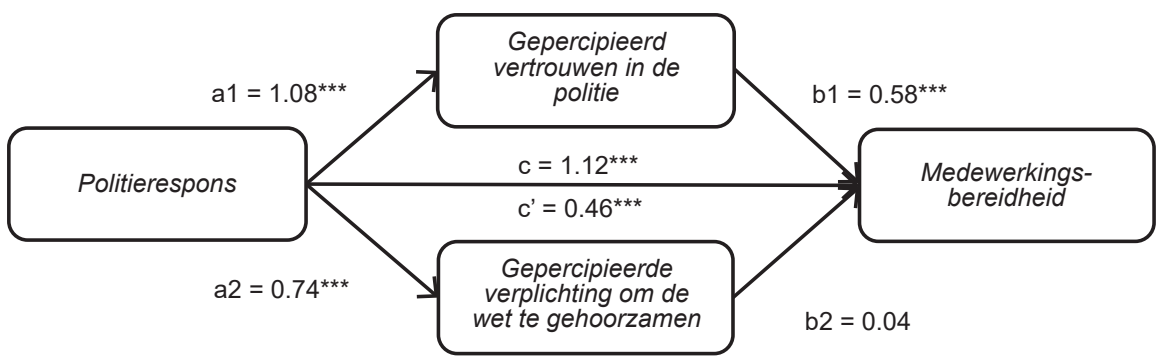

Figuur $3 \quad \begin{aligned} & \text { Meervoudig mediatiemodel van het theoretisch kader in de huidige } \\ & \text { studie. De gestandaardiseerde regressiecoëfficiënten op basis van } \\ & \text { bootstrap-analyse zijn weergegeven naast de paden }(n=276)\end{aligned}$

spons een positief en direct effect heeft op de medewerkingsbereidheid (Conaway \& Lohr, 1994; Johnson, 2007; Xie e.a., 2006; vgl. Hickman \& Simpson, 2003; Wheller e.a., 2013). De huidige studieresultaten laten zien dat in het bijzonder een negatieve politierespons een schadelijk effect lijkt te hebben op de medewerkingsbereidheid onder mock slachtoffers in vergelijking met het hebben van positief contact met de politie of geen contact met de politie hebben (ondersteuning hypothese $\mathrm{H} 1 \mathrm{~b}$ ). Daarentegen lijkt een positieve politierespons slechts een minimaal of geen positief effect te hebben op medewerkingsbereidheid in vergelijking met het niet hebben van contact met de politie (verwerping hypothese H1a). Dit suggereert dat mock slachtoffers mogelijk al medewerkingsbereid zijn en agenten weinig kunnen doen om dit verder te verhogen. Agenten dienen vooral alert te zijn om medewerkingsbereidheid niet te verlagen.

Overeenkomstig de hypotheses $\mathrm{H} 2 \mathrm{a}$ en $\mathrm{H} 2 \mathrm{~b}$ en eerder onderzoek onder echte slachtoffers van criminaliteit vonden we een positief en direct effect van de politierespons op beide indicatoren van legitimiteit in de huidige studie (zie Brathwaite \& Yeboah, 2004; Elliott e.a., 2011; Laxminarayan \& Pemberton, 2014; Wemmers, 1996). Daarnaast impliceren de resultaten van de huidige studie dat gepercipieerd vertrouwen in de politie direct gerelateerd is aan de medewerkingsbereidheid met de politie. Dit is consistent met ons theoretisch kader en eerder onderzoek onder echte slachtoffers van geweldsmisdrijven (Kääriäinen \& Sirén, 2011; Murphy \& Barkworth, 2014). Desalniettemin werden in deze studies gemixte resultaten gerapporteerd voor echte slachtoffers van andere typen delicten (zie Kääriäinen \& Sirén, 2011; Murphy \& Barkworth, 2014). Het zou kunnen dat de aard van deze relatie afhangt van het type delict waar slachtoffers van geleden hebben. Toekomstig onderzoek zou ons onderzoeksdesign kunnen repliceren en daarbij in plaats van een geweldsdelictscenario bijvoorbeeld een vermogensdelictscenario kunnen gebruiken. Op deze manier kan meer informatie worden verkregen over de invloed van het type delict op de relatie tussen gepercipieerd vertrouwen in de politie en medewerkingsbereidheid.

In aanvulling op de directe relaties tussen de politierespons en gepercipieerd vertrouwen in de politie en tussen het gepercipieerd vertrouwen in de politie en medewerkingsbereidheid blijkt uit een mediatieanalyse dat het effect van de poli- 
tie op medewerkingsbereidheid gedeeltelijk indirect verloopt via gepercipieerde politielegitimiteit in termen van gepercipieerd vertrouwen in de politie (ondersteuning hypothese $\mathrm{H} 2 \mathrm{c}$ ), maar niet door gepercipieerde politielegitimiteit in termen van gepercipieerde verplichting om de wet te gehoorzamen (verwerping hypothese H2d). Dat de indirecte relatie tussen de politierespons en medewerkingsbereidheid via gepercipieerde verplichting om de wet te gehoorzamen niet significant was, is te wijten aan het ontbreken van een significant direct verband tussen gepercipieerde verplichting om de wet te gehoorzamen en medewerkingsbereidheid. Hoewel deze laatste bevinding tegengesteld is aan ons theoretisch kader, is het in overeenstemming met eerder onderzoek onder echte slachtoffers van criminaliteit (Kochel e.a., 2013). Aangezien gepercipieerde verplichting om de wet te gehoorzamen een indicator is van gepercipieerde legitimiteit, werd verwacht dat het samen zou hangen met medewerkingsbereidheid. Een verklaring voor het niet vinden van een significante relatie zou kunnen zijn dat gepercipieerde verplichting om de wet te gehoorzamen betrekking heeft op passief gedrag, in plaats van actieve medewerking (Tyler \& Jackson, 2013). Deze redenering wordt ondersteund door de bevindingen van Kochel e.a. (2013), die geen significante relatie rapporteerden tussen percepties van slachtoffers om de wet te gehoorzamen en medewerking met de politie. Hetzelfde geldt voor onderzoeken onder het algemene publiek, waarbij de relatie tussen gepercipieerde verplichting om de wet of de politie te gehoorzamen en medewerkingsbereidheid gewoonlijk minder sterk is dan tussen gepercipieerd vertrouwen in de politie en medewerkingsbereidheid (bijv. Reisig e.a., 2007; Tankebe, 2009; Sunshine \& Tyler, 2003).

\section{Studiebeperkingen}

Bij het interpreteren van de bevindingen van de huidige studie moet een aantal beperkingen in acht genomen worden. Ten eerste is de externe validiteit van deze studie beperkt doordat gebruik gemaakt is van een vignettenexperiment met behulp van een convenience-steekproef van studenten in plaats van echte slachtoffers van criminaliteit. Vignettenstudies zijn echter vaker gebruikt om factoren te exploreren die de medewerkingsbereidheid van slachtoffers zouden kunnen beïnvloeden (bijv. Boekhoorn \& Tolsma, 2015; Goudriaan \& Nieuwbeerta, 2007; Tolsma e.a., 2012). Ter illustratie, in de studie van Tolsma e.a. (2012) werden de duur en flexibiliteit (de mogelijkheid om aangifte te doen buiten kantoortijden), de methode van aangifte doen (per telefoon, via internet of op het politiebureau), anoniem aangifte doen en aanmoediging van politieagenten om aangifte te doen gemanipuleerd om het effect hiervan op de aangiftebereidheid van mock slachtoffers te onderzoeken. De auteurs concludeerden dat de politie mogelijk factoren van het aangifteproces kan aanpassen die onder directe controle van de politie staan (zoals de duur en methoden van aangifte doen) en dat dergelijke aanpassingen zouden leiden tot hogere aangiftecijfers, in het bijzonder voor minder zware delicten. Een ander voorbeeld van een vignettenstudie waarin de politierespons werd gemanipuleerd, hoewel niet onder mock slachtoffers maar onder mock getuigen, is de studie van Haas e.a. (2014). Zij onderzochten onder andere het 
effect van de politierespons op vertrouwen in de politie en vonden ondersteuning voor een positief verband. In dit onderzoek werden twee condities met betrekking tot de politierespons vergeleken. In de ene conditie nam de politie actief contact op met het slachtoffer nadat zij beveiligingstapes had verzonden, en in de andere conditie nam de politie geen contact op met het slachtoffer na het verzenden van beveiligingstapes en nadat het slachtoffer de politie zelf benaderd had, werd haar verteld dat de politie geen tijd had om de zaak in behandeling te nemen. In de eerste conditie rapporteerden mock getuigen significant hoger gepercipieerd vertrouwen in de politie dan in de tweede conditie. Juist vanwege ethische aspecten die een manipulatie van de politierespons in het echte leven met zich mee zou kunnen brengen, is de huidige vignettenstudie een belangrijke eerste stap om de relatie tussen de politierespons en medewerkingsbereidheid te exploreren. Naar aanleiding van de huidige studieresultaten zou in een vervolgonderzoek een veldexperiment uitgevoerd kunnen worden, waarbij een groep agenten specifiek getraind wordt in het bieden van een procedureel rechtvaardige bejegening en in het communiceren over opsporingsactiviteiten en een andere groep agenten niet, naar de benadering van Wheller e.a. (2013). Op die wijze kan causaliteit getoetst worden, zonder af te doen aan de externe validiteit van studieresultaten.

Ten tweede zou de betrouwbaarheid van de resultaten beperkt kunnen zijn door de focus op de medewerkingsbereid van mock slachtoffers in plaats van daadwerkelijke medewerking. Hoewel een meta-analyse suggereert dat gerapporteerde intenties en daadwerkelijk gedrag met elkaar samenhangen (zie Kim \& Hunter, 1993), weten we niet in hoeverre participanten daadwerkelijk medewerking zullen verlenen aan de politie in geval van toekomstig slachtofferschap. Vervolgonderzoek zou daarom idealiter de focus van de huidige studie kunnen verbreden door daadwerkelijke medewerking te includeren, bijvoorbeeld door participanten over langere tijd te volgen om na te gaan of zij medewerking aan de politie verlenen als zij in het echte leven slachtoffer van criminaliteit zijn geworden. Een ander gevolg van de focus op de medewerkingsbereidheid is de mogelijkheid dat participanten sociaal wenselijk antwoordden. Echter, de gemiddelde scores op medewerkingsbereidheid over de condities in de huidige studie verschillen van elkaar op verwachte wijze, implicerend dat de antwoorden van mock slachtoffers ten minste op enige wijze werden beïnvloed door het scenario.

Een andere beperking die genoemd moet worden, is de operationalisatie van gepercipieerde legitimiteit in de huidige studie. Het meten van gepercipieerde legitimiteit is onderwerp van een voortdurend debat en heeft geresulteerd in verscheidene manieren om dit concept te meten, waarin traditioneel gepercipieerd vertrouwen en gepercipieerde verplichting tot gehoorzaamheid zijn opgenomen (zie Jackson \& Gau, 2016 voor een overzicht). In de voorliggende studie werd gepercipieerde legitimiteit geoperationaliseerd door gepercipieerd vertrouwen in de politie en gepercipieerde verplichting om de wet te gehoorzamen. Gepercipieerd vertrouwen in de politie werd indirect gemeten in termen van ondersteuning aan de politie in plaats van meer directe metingen (bijv. 'Op een 1 tot 7-schaal, hoeveel vertrouwen heeft $\mathrm{u}$ in de politie?'), omdat dit meer betrouwbare resultaten zou opleveren (Van Damme e.a., 2012). We hebben de gepercipieerde verplichting om de wet te gehoorzamen gemeten in plaats van de gepercipieerde ver- 
plichting om de politie te gehoorzamen, omdat dit mogelijk meer overeenkomt met de intrinsieke verantwoordelijkheidsgevoelens van mensen om zich te gedragen in overeenstemming met de sociale normen en waarden en normen in de samenleving, zelfs wanneer er geen externe prikkels zijn om dat te doen (Tyler, 2006). De operationalisatie van gepercipieerde legitimiteit in de huidige studie is overgenomen van Tyler (2006) en Wemmers (1996). Toekomstige studies kunnen echter andere operationalisaties hanteren, maar voorgaand onderzoek onder het algemene publiek suggereert dat resultaten vergelijkbaar zijn, ondanks kleine verschillen in operationalisatie van dit concept (bijv. Tyler, 2006; Reisig e.a., 2007; Tankebe, 2009; Sunshine \& Tyler, 2003).

De huidige studie is beperkt tot de politierespons gedurende de opsporingsfase. Vervolgonderzoek zou ook de uitkomst van de zaak in de studie kunnen betrekken (bijv. of de dader werd gepakt door de politie). Daarmee zou toekomstig onderzoek de relatieve impact van het proces en de uitkomst op de medewerkingsbereidheid in geval van toekomstig slachtofferschap kunnen onderzoeken (zie Laxminarayan \& Pemberton, 2013).

Ten slotte zijn de bevindingen gebaseerd op crosssectionele data, aangezien alle concepten in de huidige studie op hetzelfde moment gemeten zijn. Dit zou de externe validiteit van de resultaten hebben kunnen belemmeren. Toekomstige studies zouden het huidige studiedesign kunnen verbeteren door de concepten over verschillende tijdsperioden te meten en daarmee na te gaan of de verbanden standhouden over tijd.

\section{Conclusie}

Ondanks deze beperkingen is deze studie de eerste die exploreert of de politierespons causaal verband houdt met medewerkingsbereidheid aan de politie en of deze relatie gemedieerd wordt door gepercipieerde legitimiteit. Door gebruik te maken van een vignettenexperiment werden participanten willekeurig verdeeld over verschillende condities en werd de politierespons binnen deze condities gemanipuleerd op een wijze die ongepast zou zijn in het echte leven. De resultaten suggereren dat een negatieve politierespons in een eerdere zaak zou kunnen verklaren waarom vooral herhaalde slachtoffers, in vergelijking met personen die voor het eerst slachtoffer worden, minder bereid lijken te zijn om medewerking te verlenen aan de politie. De bevindingen suggereren bovendien dat dit ten minste gedeeltelijk komt door de invloed van de politierespons op het gepercipieerd vertrouwen in de politie. Dit is niet alleen wetenschappelijk interessant, maar ook van praktisch belang voor de politie, omdat het impliceert dat agenten in staat kunnen zijn om verminderde medewerkingsbereidheid onder herhaalde slachtoffers te beperken door hen op rechtvaardige wijze te bejegenen en door op adequate wijze opsporingsactiviteiten uit te voeren en daarover te communiceren in een eerder incident. Of dit echter het geval is gedurende interacties in het echte leven, zou onderwerp van een toekomstig veldexperiment kunnen zijn. 


\section{Literatuur}

Alwin, D.F. \& Hauser, R.M. (1975). The decomposition of effects in path analysis. American Sociological Review, 40(1), 37-47.

Aviv, G. \& Weisburd, D. (2016). Reducing the gap in perceptions of legitimacy of victims and non-victims: the importance of police performance. International Review of Victimology. Online publicatie. doi: 10.1177/0034523715627041

Boekhoorn, P. \& Tolsma, J. (2015). De aangifte van delicten bij de 'multichannelstrategie' van de politie. Nijmegen: Bureau Boekhoorn Sociaal-wetenschappelijk Onderzoek en Radboud Universiteit Nijmegen.

Bradford, B. \& Jackson, J. (2016). Cooperating with the police as informal social control. Trust and neighbourhood concerns as predictors of public assistance. Nordisk politiforskning (Nordic Journal of Policing Studies), 3(2), 109-129.

Brathwaite, F. \& Yeboah, D.A. (2004). Victims of crime in the criminal justice system in Barbados. Journal of Criminal Justice, 32(5), 431-442.

Conaway, M.R. \& Lohr, S.L. (1994). A longitudinal analysis of factors associated with reporting violent crimes to the police. Journal of Quantitative Criminology, 10(1), 23-39.

De Mesmaecker, V. (2014). Perceptions of criminal justice. Oxon: Routledge.

Dijk, J.J.M. van (2001). Attitudes of victims and repeat victims toward the police. Results of the International Crime Victims Survey. Crime Prevention Studies, 12, 27-52.

Elliott, I., Thomas, S.D.M. \& Ogloff, J.R.P. (2011). Procedural justice in contacts with the police. Testing a relational model of authority in a mixed methods study. Psychology, Public Policy, and Law, 17(4), 592-610.

Elliott, I., Thomas, S.D.M. \& Ogloff, J.R.P. (2012). Procedural justice in contacts with the police. The perspective of victims of crime. Police Practice and Research: An International Journal, 13(5), 437-449.

Erdfelder, E., Faul, F. \& Buchner, A. (1996). GPOWER: a general power analysis program. Behavioural Research Methods, Instruments, \& Computers, 28(1), 1-11.

Faul, F. \& Erdfelder, E. (1992). GPOWER: a priori-, post hoc-, and compromise power analyses for MS-DOS [Computer program]. Bonn, Germany: Bonn University.

Fleming, J. \& McLaughlin, E. (2012). Researching the confidence gap: theory, method, policy. Policing \& Society, 22(3), 261-269.

Goudriaan, H. \& Nieuwbeerta, P. (2007). Contextual determinants of juveniles' willingness to report crimes. Journal of Experimental Criminology, 3(2), 89-111.

Haas, N.E., Keijser, J.W. de \& Bruinsma, G.J.N. (2014). Public support for vigilantism, confidence in police \& police responsiveness. Policing and Society, 24(2), 224-241.

Hickman, L.J. \& Simpson, S.S. (2003). Fair treatment or preferred outcome? The impact of police behavior on victim reports of domestic violence incidents. Law \& Society Review, 37(3), 607-634.

Ipsos MORI (2003). Experiences of the criminal justice system - victims and witnesses of crime. Research study conducted for the audit commission. Beschikbaar via www.ipsos-mori. com/Assets/Docs/Archive/Polls/auditcommission.pdf.

Jackson, J. \& Gau, J.M. (2016). Carving up concepts? Differentiating between trust and legitimacy in public attitudes towards legal authority. Forthcoming in: E. Shockley, T.M.S. Neal, L. PytlikZillig \& B. Bornstein (eds.). Interdisciplinary perspectives on trust. Towards theoretical and methodological integration. New York: Springer.

Jackson, J., Bradford, B., Hough, M., Myhill A., Quinton, P. \& Tyler, T.R. (2012). Why do people comply with the law? Legitimacy and the influence of legal institutions. British Journal of Criminology, 52(6), 1051-1071. 
Johnson, I.M. (2007). Victims' perceptions of police response to domestic violence incidents. Journal of Criminal Justice, 35(5), 498-510.

Kääriäinen, J.T. \& Sirén, R. (2011). Support for the police, generalized trust and reporting crime. European Journal of Criminology, 8(1), 65-81.

Kim, M. \& Hunter, J.E. (1993). Attitude-behavior relations: a meta-analysis of attitudinal relevance and topic. Journal of Communication, 43(1), 101-142.

Kochel, T.R., Parks, R. \& Mastrofski, S.D. (2013). Examining police effectiveness as a precursor to legitimacy and cooperation with police. Justice Quarterly, 30(5), 895-925.

Koster, N.N. (2017). Victims' perceptions of police officers' behaviour as a predictors of victim cooperation in the Netherlands: a prospective analysis. Psychology, Crime, and Law, 23(3), 201-220.

Koster, N.N., Kuijpers, K.F., Kunst, M.J.J. \& Leun, J.P. van der (2016). Crime victims' perceptions of police behaviour, legitimacy, and cooperation. A review of the literature. Victims and Offenders: An International Journal of Evidence-based Research, Policy, and Practice, 11(3), 392-435.

Laxminarayan, M.S. \& Pemberton, A. (2013). Victim satisfaction with criminal justice: a systematic review. Victims and Offenders: An International Journal of Evidence-based Research, Policy, and Practice, 8(2), 119-147.

Laxminarayan, M.S. \& Pemberton, A. (2014). The interaction of criminal procedure and outcome. International Journal of Law and Psychiatry, 37(6), 564-571.

Leeper Piquero, N. \& Piquero, A.R. (2006). Control balance and exploitative corporate crime. Criminology, 44(2), 397-430.

Mallinckrodt, B., Abraham, W.T., Wei, M. \& Russel, D.W. (2006). Advances in testing the statistical significance of mediation effects. Journal of Counseling Psychology, 53(3), 372-378.

Murphy, K. \& Barkworth, J. (2014). Victim willingness to report crime to police. Does procedural justice or outcome matter most? Victims and Offenders: An International Journal of Evidence-based Research, Policy, and Practice, 9(2), 178-204.

Preacher, K.J. \& Hayes, A.F. (2008). Asymptotic and resampling strategies for assessing and comparing indirect effects in multiple mediator models. Behavior Research Methods, 40(3), 879-891.

Preacher, K.J. \& Kelley, K. (2011). Effect size measures for mediation models. Quantitative strategies for communicating indirect effects. Psychological Methods, 16(2), 93-115.

Reisig, M.D., Bratton, J. \& Gertz, M.G. (2007). The construct validity and refinement of process-based policing measures. Criminal Justice and Behavior, 34(8), 1005-1028.

Shapland, J., Willmore, J. \& Duff, P.R. (1985). Victims in the criminal justice system. Aldershot: Gower.

Sobel, M.E. (1982). Asymptotic confidence intervals for indirect effects in structural equation models. In: S. Leinhardt (ed.). Sociological methodology. Washington, DC: American Sociological Association, 290-312.

Sunshine, J. \& Tyler, T.R. (2003). The role of procedural justice and legitimacy in shaping public support for policing. Law \& Society Review, 37(3), 513-547.

Tankebe, J. (2009). Public cooperation with the police in Ghana. Does procedural fairness matter? Criminology, 47(4), 1265-1293.

Teare, M.D., Dimairo, M., Shephard, N., Hayman, A., Whitehead, A. \& Walters, S.J. (2014). Sample size requirements to estimate key design parameters from external pilot randomised controlled trials: a simulations study. Trials, 15, 264-277.

Tolsma, J., Blaauw, J. \& Grotenhuis, M. te (2012). When do people report crime to the police? Results from a factorial survey design in the Netherlands, 2010. Journal of Experimental Criminology, 8(2),117-134. 
Tyler, T.R. (2006). Why people obey the law. Princeton, NJ: Princeton University Press. Tyler, T.R. (2011). Why do people cooperate. The role of social motivations. Princeton. NJ: Princeton University Press.

Tyler, T.R. \& Blader, S.L. (2003). The group engagement model: procedural justice, social identity, and cooperative behavior. Personality and Social Psychology Review, 7(4), 349-361.

Tyler, T.R. \& Huo, Y.J. (2002). Support for the law: encouraging public cooperation with police and courts. New York: Russell Sage Foundation.

Tyler, T.R. \& Jackson, J. (2013). Popular legitimacy and the exercise of legal authority. Motivating compliance, cooperation and engagement. Psychology, Public Policy, and Law, 20(1), 78-95.

Tyler, T R. \& Lind, E.A. (1992). A relational model of authority in groups. Advances in Experimental Social Psychology, 25, 115-191.

Van Damme, A., Pauwels, L. \& Haas, N. (2012). Exploring the factor structure of measures of confidence in procedural justice and performance of the criminal justice system by actor. A latent-variables approach. In: M. Cools, B. De Ruyver, M. Easton, P. Pauwels, P. Ponsaers, G. Vande Walle, T. Vander Beken, F. Vander Laenen, A. Verhage, G. Vermeulen \& G. Vynckier (eds.). Social conflicts, citizens and policing. Antwerp: Maklu, 119-140.

Van den Bos, K., Vermunt, R. \& Wilke, H.A.M. (1997). Procedural and distributive justice: What is fair depends more on what comes first than on what comes next. Journal of Personality and Social Psychology, 72(1), 95-104.

Wemmers, J.M. (1996). Victims in the criminal justice system. Amsterdam: Kugler.

Wheller, L., Mills, A. \& Quinton, P. (2013). The Greater Manchester Police procedural justice training experiment. Beschikbaar via libary.college.police.uk.

Xie, M., Pogarsky, G., Lynch, J.P. \& McDowell, D. (2006). Prior police contact and subsequent victim reporting. Results from the NCVS. Justice Quarterly, 23(4), 481-501.

\section{Appendix}

Scenario voor de positieve politieresponsconditie:

Wanneer je laat op de avond onderweg bent naar huis, word je lastig gevallen door een man. Hij wil je portemonnee stelen. Wanneer je die niet direct geeft, slaat hij je hard in je gezicht. Vervolgens geeft hij je een trap in je maag, waardoor je op de grond valt. Hij pakt je portemonnee, rent ermee weg naar zijn scooter die iets verderop staat en scheurt weg. Je kent de dader van naam, maar je hebt niet eerder met deze persoon gesproken en je weet niet waar hij woont. Je gezicht en maag doen pijn, maar je hoeft niet naar een arts.

Geschrokken haast je je naar huis en bel je de politie.

Twee agenten arriveren snel. Als je de deur voor ze open doet, zien ze dat je geschrokken bent en de agenten vragen je vriendelijk hoe het met je gaat en of je veel pijn hebt. Als je zegt dat het wel gaat, geven de agenten aan dat ze je melding hebben ontvangen en dat in deze buurt vaker roofover- 
vallen plaatsvinden. Dan vragen ze geïnteresseerd: 'Zou je willen vertellen wat er precies gebeurd is?' Nadat je jouw verhaal hebt verteld, stellen ze nog een aantal vragen: 'Waar kwam je vandaan?'; 'Hoe laat was het toen je vertrok?'; 'Via welke route ben je thuis gekomen?'; 'Welk geslacht had de dader?'; 'Welke afkomst had de dader?' Nadat je hebt geantwoord zeggen ze: 'We hebben voldoende informatie. We vinden het heel vervelend voor je dat dit je overkomen is en wij willen ook graag de dader pakken. Je hoort nog van ons.'

$\mathrm{Na}$ twee weken gaat het een stuk beter met je en word je gebeld door één van de agenten met de mededeling dat ze buurtonderzoek gedaan hebben en dat ze nog bezig zijn met de zaak.

Scenario voor de negatieve politieresponsconditie:

Wanneer je laat op de avond onderweg bent naar huis, word je lastig gevallen door een man. Hij wil je portemonnee stelen. Wanneer je die niet direct geeft, slaat hij je hard in je gezicht. Vervolgens geeft hij je een trap in je maag, waardoor je op de grond valt. Hij pakt je portemonnee, rent ermee weg naar zijn scooter die iets verderop staat en scheurt weg. Je kent de dader van naam, maar je hebt niet eerder met deze persoon gesproken en je weet niet waar hij woont. Je gezicht en maag doen pijn, maar je hoeft niet naar een arts.

Geschrokken haast je je naar huis en bel je de politie.

Het duurt lang voordat twee agenten arriveren. Als je de deur voor ze open doet, zien ze dat je geschrokken bent, maar de agenten gaan hier niet op in. De agenten geven aan dat ze je melding hebben ontvangen en dat in deze buurt vaker roofovervallen plaatsvinden. Dan zeggen ze kortaf: 'Je hoeft ons niet meer te vertellen wat er gebeurd is hoor, we kennen al die verhalen wel'. Ze hebben wel een aantal vragen: 'Was de dader een man?'; 'Was de dader een allochtoon?' Op jouw antwoord dat de dader blank was, vragen de agenten: 'Weet je dat zeker?' Nadat je hebt geantwoord dat je dat zeker weet, zeggen ze: 'We hebben voldoende informatie. We bekijken nog wel of we er iets mee kunnen. Je hoort nog van ons.'

$\mathrm{Na}$ twee weken gaat het een stuk beter met je, maar heb je niets meer van de politie gehoord. 